International Journal of Social Science And Human Research

ISSN(print): 2644-0679, ISSN(online): 2644-0695

Volume 05 Issue 02 February 2022

DOI: 10.47191/ijsshr/v5-i2-24, Impact factor-5.586

Page No: 578-582

\title{
Democratic Principles-Based Reconstruction of Presidential Threshold Provisions on Indonesian Presidential Elections
}

\author{
Muh. As Sidiq ${ }^{1}$, Fifiana Wisnaeni ${ }^{2}$ \\ ${ }^{1,2}$ Master of Law Study Program, Faculty of Law, Diponegoro University
}

\begin{abstract}
The problem raised in this paper is how to reconstruct the Presidential Threshold Provisions for the Election of the President and Vice President in Indonesia, based on the principles of democratic elections. In this paper, the author guided Constructivism as a paradigm and used Legal Constructivism as an approach, which will lead to conceptual ideas. The results of this study that the ideal setting regarding the provisions of the Presidential Threshold for the nomination of President and Vice President in Indonesia would be more appropriate if it can be $0 \%$. This is an effort to present many qualified candidates for President and Vice President so that the public can see a more diverse range of pairs and will also encourage the application of the principles of democratic elections.
\end{abstract}

KEYWORDS: Democracy; Presidential Threshold; Election of President and Vice President

\section{INTRODUCTION}

Indonesia is a constitutional state that has sovereignty over the people and is a state in the form of a republic as stipulated in the 1945 Constitution of the Republic of Indonesia. As a state of law, Indonesia adheres to the principles of democracy, recognizes and protects human rights, and has an independent judiciary which does not impartial. The logical consequence of Indonesia as a state of law is that every state administration must be based on law. ${ }^{1}$

In a state of law, state power is regulated and divided according to law. The power and actions of the ruler must be based on or sourced from the law, and it is the law that is to be enforced and implemented. Behind the rule of law and the rule of law is essentially the supremacy and sovereignty of the people as a whole, which is generally manifested in modern countries through democratically elected representatives. In current state practice in Indonesia, the manifestation of the people is in their representatives who are elected through general elections. ${ }^{2}$

Indonesia is a country that adheres to a democratic system. The main principle of a democracy is the government of, by, and for the people. ${ }^{3}$ This can be seen from the purpose of the formation of the state as stated in the Preamble of the 1945 Constitution of the Republic of Indonesia where the purpose of the state is to protect the entire Indonesian nation and the entire homeland of Indonesia and to promote the general welfare, educate the nation's life, and participate in implementing world order based on independence, eternal peace, and social justice, the Indonesian state was formed based on the sovereignty of the people as stipulated in Article 1 Paragraph (2) of the 1945 Constitution of the Unitary State of the Republic of Indonesia.

Democracy is the best principle and system in the state administration system, it cannot be denied. The treasures of political thought and performance in various countries have come to a common ground on this: democracy is the best choice out of various other options. A study report sponsored by a United Nations organ, UNESCO, in the early 1950s stated that there was not a single response that rejected "democracy" as the most appropriate and ideal foundation for all modern political organizations and organizations. ${ }^{4}$

Based on and understanding democracy, the Indonesian state adheres to a government system based on people's sovereignty or commonly known as a "democratic" government system. Democracy comes from the Greek, demos (the people), and cratein (government) which means the government of the people. ${ }^{5}$ Democracy requires general elections to elect

\footnotetext{
${ }^{1}$ Jimly Asshiddiqie, 'Gagasan Negara Hukum Indonesia', Jurnal Pembinaan Hukum Nasional, 2.3 (2017), 1-17. p. 4.

2 Tetep Jamaludin, 'Kesuksesan Dan Problematika Pemilihan Kepala Daerah Secara Langsung Di Indonesia', Jurnal Etika \& Pemilu, 4.1 (2018), 75-89.p.78.

${ }^{3}$ and Carl F. Mittendorff Alok K. Bohara, Neil J. Mitchell, 'Compound Democracy and the Control of Corruption: A CrossCountry Investigation', The Policy Studies Journal, 32.4 (2004), 481-499.p. 491

${ }^{4}$ Ni'Matul Huda, Dinamika Ketatanegaraan Indonesia Dalam Putusan Mahkamah Konstitusi (Yogyakarta: FH UII Press, 2011). P.51.

${ }^{5}$ Fadjar A.Mukti, Tipe Negara Hukum (malang: bayumedia, 2004).p.75
} 


\section{Democratic Principles-Based Reconstruction of Presidential Threshold Provisions on Indonesian Presidential Elections}

representatives of the people which must be held periodically on the principles of direct, general, free, secret, honest and fair (hereinafter referred to as luberjurdil).

General elections or known as elections are the embodiment of real people sovereignty. It can be said that if there is no election then the people are not sovereign. Because with elections the people can determine who will be their representatives and leaders in the seat of government so that they can become state operators and reach the people's expectations. ${ }^{6}$

After the amendment to Law Number 42 of 2008 concerning General Elections for the President and Vice President, Law Number 7 of 2017 concerning General Elections has given birth to several important points that have been ratified, one of which is related to the presidential threshold. The presidential threshold is a threshold rule for a political party or a combination of political parties to be able to nominate candidates for President and Vice President in the 2019 Election. For the 2019 presidential election, the presidential threshold used was 20 percent. This was in accordance with Article 222 of Law Number 7 of 2017 concerning General Elections: "A pair of candidates are proposed by a Political Party or a Combined Election Contesting Political Party that meets the requirements for obtaining seats of at least 20\% (twenty percent) of the total seats in the DPR (House of Representatives) or obtaining 25\% (twenty-five percent) of the valid votes nationally in the previous election for DPR members."

The provisions on the Presidential Threshold for the nomination of President and Vice President in Indonesia can be seen in Article 222 of Law Number 7 of 2017 concerning General Elections. Based on Article 222 of Law Number 7 of 2017 concerning General Elections two sentences are included and are different from Article 6A Paragraph (2) of the 1945 Constitution of the Republic of Indonesia. Which is an addition to Article 6A Paragraph (2) of the 1945 Constitution of the Republic of Indonesia. Article 6A Paragraph (2) of the 1945 Constitution of the Republic of Indonesia reads as follows: "The pair of candidates for President and Vice President are proposed by a political party or coalition of political parties participating in the general election before the implementation of the general election."

Meanwhile, Article 222 of the Law of the Republic of Indonesia Number 7 of 2017 concerning General Elections reads, namely: "The pair of candidates are proposed by a political party or coalition of political parties participating in the election who fulfills the requirements for obtaining seats of at least $20 \%$ of the total seats in the DPR or obtaining $25 \%$ of valid votes nationally in the previous election for members of the DPR."

Thus, the difference between Article 6A Paragraph 2 of the 1945 Constitution of the Republic of Indonesia and Article 222 of the Republic of Indonesia Law Number 7 of 2017 concerning General Elections, (State Gazette of the Republic of Indonesia of 2017 Number 182, Supplement to the State Gazette of the Republic of Indonesia Year 2017 Number 6109), is the addition of the sentence: Those who meet the requirements for obtaining seats at least $20 \%$ of the total seats in the DPR or obtaining $25 \%$ of nationally valid votes in the previous election for DPR members.

The presidential threshold policy is based on the results of the election for members of the People's Representative Council of the previous period as well as the norms of Article 222 of Law Number 7 of 2017 concerning General Elections which were born from the attribution authority granted from Article 6A paragraph (5) and Article 22E paragraph (6) of the 1945 Constitution of the Republic of Indonesia that can be studied in depth whether it is appropriate or whether there is a conflict of norms (geschijd van normen).

Talking about the state of art national index, the content of this paper is different from other writings. Abdul Ghoffa's journal with the title "Problematika Presidential Threshold: Putusan Mahkamah Konstitusi dan Pengalaman di Negara Lain (Problematics of the Presidential Threshold: Constitutional Court Decisions and Experiences in Other Countries)"7 focuses on reviewing the Constitutional Court's Decision regarding the Presidential Threshold issue as well as seeing whether other countries have also implemented the system. Meanwhile, this paper focuses on how to reconstruct the Presidential Threshold Provisions for the Presidential Election in Indonesia Based on Democratic Election Principles.

Journal of Sholahuddin Al-Fatih "Akibat Hukum Regulasi Tentang Threshold dalam Pemilihan Umum Legislatif Dan Pemilihan Presiden (The Effects of Regulatory Law on Thresholds in Legislative and Presidential Elections)" 8 focuses on reviewing the legal consequences of regulations regarding thresholds in the legislative and presidential elections after the Constitutional Court Decisions Number 52/PUU-X/2012 and Number 14/PUU-XI/2013. The difference in this paper focuses on the Reconstruction of Presidential Threshold Provisions for Presidential Elections in Indonesia Based on Democratic Election Principles.

Starting from the description stated above, the main problems in this study lead to first, how is the regulation of the Presidential Threshold provisions for the Presidential Election in Indonesia, and second, the reconstruction of the Presidential Threshold provisions for the Presidential Election in Indonesia based on the principles of the democratic election.

\footnotetext{
${ }^{6}$ Jimly Asshiddiqie, Pokok-Pokok Hukum Tata Negara Indonesia Pasca Reformasi (Jakarta: Buana Ilmu Populer, 2007$)$.p.34.

7 Abdul Ghoffar, 'Problematika Presidential Theresold: Putusan Mahkamah Konstitusi Dan Pengalaman Di Negara Lain', Konstitusi, 15 (2018).

${ }^{8}$ Sholahuddin Al-Fatih, 'Akibat Hukum Regulasi Tentang Thersold Dalam Pemiliham Umum Legislatif Dan Pemilihan Presiden', Yudisial, 12 (2019).
} 


\section{Democratic Principles-Based Reconstruction of Presidential Threshold Provisions on Indonesian Presidential Elections}

\section{RESEARCH METHODS}

The research approach method used was a law doctrinal approach. This method emphasizes the concept that law can be viewed as a set of laws and regulations that are systematically arranged based on a certain order. The order must have a distinctive feature, namely the existence of harmonization or synchronization, both vertical and horizontal synchronization. ${ }^{9}$

In this paper, the author was guided by Legal Constructivism as a Paradigm or a set of basic beliefs. Legal Constructivism interprets the law as mental construction the same way law as experiential realities. It means that the law for Legal Constructivism is actually a mental construction that is relative, plural, diverse, intangible, local, and specific. Although similar elements can be found in individuals, community groups, and different cultures. ${ }^{10}$ As a result, this paper led to a conceptual idea. The conceptual approach that moves from the views and doctrines that develop in the science of law by studying them will find ideas that give birth to legal understandings, legal concepts, and legal principles relevant to the problems written.

\section{RESULTS AND DISCUSSION}

\section{Presidential Threshold Provisions for the General Election of President and Vice President in Indonesia}

The presidential threshold is the minimum threshold required for the nomination of a president and vice president based on the number of voting seats in parliament or the number of nationally valid votes obtained from political parties or coalitions of political parties through elections. ${ }^{11}$ The Presidential Threshold regulation is regulated in Law Number 7 of 2017 concerning General Elections which states that "a Candidate Pair is proposed by a Political Party or a Combined Election Contesting Political Party that meets the requirements for obtaining seats of at least $20 \%$ (twenty percent) of the total DPR seats or obtain $25 \%$ (twenty-five percent) of the nationally valid votes in the previous election for DPR members."

The regulation related to the Presidential Threshold as regulated in Law Number 7 of 2017 concerning General Elections is an elaboration of the 1945 Constitution of the Republic of Indonesia which states that "The pair of candidates for President and Vice President are proposed by a political party or coalition of political parties participating in the general election before the implementation of the general election." The provisions contained in the 1945 Constitution of the Republic of Indonesia Article 6A paragraph (2) have a difference with Article 222 of Law Number 7 of 2017 concerning General Elections. The 1945 Constitution of the Republic of Indonesia Article 6A paragraph (2) does not specify the number of votes as a condition for the nomination of a president and vice president. Article 222 of Law Number 7 of 2017 concerning General Elections explicitly stipulates the number of votes as a condition of nomination for president and vice president. The actual implementation of the Presidential Threshold was not only enforced in 2019. However, the Presidential Threshold has been implemented since the direct election of the President and Vice President, namely in 2004.

After that, the 2019 Election was regulated in Law Number 7 of 2017 concerning General Elections. This is because the 2019 elections were held simultaneously for DPR, DPD, DPRD, as well as the President and Vice President, at one time. The history of the Presidential Threshold provision is not determined by the same number of votes in determining the Presidential Threshold. ${ }^{12}$ The Presidential Threshold number of votes started from the direct election of President and Vice President in 2004 until later in 2019.

The presidential and vice-presidential elections in 2004 implemented a Presidential Threshold of 15\% of the DPR's votes or $20 \%$ of the nationally valid votes obtained by political parties or a combination of political parties in the DPR elections. The presidential and vice-presidential elections after 2004 to 2019 use the same number of Presidential Thresholds, namely $20 \%$ of the DPR votes or $25 \%$ of nationally valid votes obtained by political parties or a combination of political parties in the DPR elections. In addition, there is a legal basis governing the two presidential and vice-presidential elections. Law Number 42 of 2008 concerning the General Election of the President and Vice President was used as the legal basis for the 2009 and 2014 presidential and vice-presidential elections.

\section{Democratic Principles-Based Reconstruction of Presidential Threshold Provisions on Indonesian Presidential Elections}

Since Indonesia's independence, until now, direct presidential elections in Indonesia have only been held 4 (four) times, namely in 2004, 2009, 2014, and lastly in 2019. The arrangements for the presidential election have also experienced various dynamics and changes. For the 2004 presidential election, the legal basis used is Law Number 32 of 2003 concerning the Election of the President and Vice President. Furthermore, for the 2009 and 2014 presidential elections, Law Number 42 of 2008 concerning the General Election of the President and Vice President was used as the legal basis. The enactment of this law is the

\footnotetext{
9 Suteki and Galang Taufani, Metodologi Penelitian Hukum (Filsafat, Teori Dan Praktik) (Depok: Rajagrafindo Persada, 2018).P.42

${ }^{10}$ Erlyn Indarti, 'Diskresi Dan Paradigma: Sebuah Telaah Filsafat Hukum', 2010.P. 32.

${ }^{11}$ Allan Fatchan Gani Wardhana Jamaluddin Ghafur, Presidential Threshold" Sejarah, Konsep Dan Ambang Batas Persyaratan

Pencalonan Dalam Tata Hukum Di Indonesia (Malang: Setara Press, 2019).p.61.

${ }^{12}$ Ghoffar.Op Cit.p.21.
} 


\section{Democratic Principles-Based Reconstruction of Presidential Threshold Provisions on Indonesian Presidential Elections}

answer to several problems that arose in the 2004 presidential election due to the lack of comprehensiveness of Law Number 23 of 2003 in regulating the holding of the presidential election. ${ }^{13}$

2019 Presidential and Vice-Presidential Election that based on Law Number 17 of 2017 also raised pros and cons in society. The law debate was regarding the requirements for the nomination of President and Vice President. The legal problem that occurred was when the simultaneous general elections in Indonesia still maintain the Presidential Threshold provisions for political parties to nominate pairs of the president and vice president candidates. This is as stated in Article 222 which reads: " The pair of candidates are proposed by a political party or coalition of political parties participating in the election who fulfills the requirements for obtaining seats of at least $20 \%$ of the total seats in the DPR or obtaining $25 \%$ of valid votes nationally in the previous election for members of the DPR."

The principles referred to are regulated in Article 22E paragraph (1) of the 1945 Constitution of the Republic of Indonesia which states that "General elections are held in a direct, general, free, secret, honest and fair manner every five years." Substantially, the norm of Article 22E paragraph (1) of the 1945 Constitution of the Republic of Indonesia contains 7 (seven) election principles, namely: direct, general, free, confidential, honest, fair, and periodic. These principles can be referred to as election principles according to the 1945 Constitution of the Republic of Indonesia. ${ }^{14}$

Based on the development of the regulation of election principles, it can be understood that the constitution requires elections to be held democratically. Elections must be conducted following the principles of democracy as intended by the 1945 Constitution of the Republic of Indonesia. The principles of democracy include essential principles and procedural principles. The essential principle is the guarantee of the right to vote as part of human rights, freedom and voting rights, and equality or equal suffrage among citizens. The procedural principles include the principle of the majority vote in the election to their constituents. Under the principles of democracy according to the 1945 Constitution of the Republic of Indonesia, the principles of democratic elections that the constitution requires are at least, namely: the principle of freedom and confidentiality of choice; The principle of equal suffrage; The principle of majority vote; The principle of certainty and honesty; and the principle of transparency and accountability.

Robert Dahl in his book simplifies democratic election standards into 5 (five) standards, namely: effective participation; equality in voting; gaining clear understanding; carrying out final oversight of the agenda; and adult involvement. ${ }^{15}$ Of the five standards, equality in voting is a standard that is directly related to elections. Meanwhile, what is meant by equality in voting is that every member or community must have an equal and effective opportunity to cast a vote and all votes must be counted equally. Equality among citizens in voting is a principle that must be applied. Equality is not only for the voting process but also in assessing votes. Every vote regardless of social, political, or economic status has the same vote with the same value. This became known as the principle of one person, one vote, one value.

The 1945 Constitution of the Republic of Indonesia mandates citizens to take an active role in the administration of government. This means that the public is given the widest possible place to participate in the general election. However, the existence of a sentence as contained in Article 222 of Law Number 7 of 2017 concerning General Elections has become a barrier for the public to be involved in democratic parties. With this Presidential Threshold, people who join political parties and those who do not lose their political rights. First, the right to run for President and Vice President. Second, the right to choose the President and Vice President freely as they wish.

Satjipto Rahardjo defines legal politics as an activity of choosing and the way to be achieved to achieve a social goal with certain laws in society, ${ }^{16}$ the purpose of this reconstruction is to determine the purpose, direction, form, as well as content of the electoral law, especially regarding the Presidential Threshold on the Election of the President and Vice President in Indonesia based on the principles of democratic elections.

Departing from Robert Dahl's opinion regarding democratic elections, the threshold of the terms or provisions of Presidential Threshold nomination of President and Vice President in Indonesia can be said to be based on the Democratic Election Principles. So how, according to the author, setting the Presidential Threshold for the nomination of President and Vice President in Indonesia is more appropriate if $0 \%$, this is also in accordance with what is mandated by the 1945 Constitution of the Republic of Indonesia contained in Article 6A Paragraph 2 which states that the President and Vice President are proposed by a political party or coalition of political parties participating in the General Election before the implementation of the General Election, meaning that the requirements to become President and Vice President only need to join a political party without having

13 Imam Nasef and Ni'Matul Huda, Penataan Demokrasi Dan Pemilu Di Indonesia Pasca Reformasi (Jakarta: Kencana, 2017).P.32.

14 Ramlan Surbakti, Integritas Pemilu 2014: Kajian Pelanggaran, Kekerasan, Dan Penyalahgunaan Uang Pada Pemilu 2014 (Jakarta: Kemitraan Partnership, 2014).p.85.

15 Robert Dahl, Perihal Demokrasi, Menelajahi Teori Dan Praktik Demokrasi Secara Singkat (Jakarta: Penerbit yayasan Obor, 2011).p.21.

${ }^{16}$ Moh Mahfud MD, Politik Hukum Di Indonesia, Cetakan ke (Jakarta: Pers, Rajawali, 2014).p.91 


\section{Democratic Principles-Based Reconstruction of Presidential Threshold Provisions on Indonesian Presidential Elections}

to be determined by the threshold as stipulated in Article 222 Law Number 7 of 2017. The $0 \%$ Threshold Provision is an effort to present many qualified candidates for President and Vice President so that people can see pairs of partners becoming more diverse. The $0 \%$ threshold becomes relevant to apply with a note that it is applied only to political parties that have passed the verification stage as participants in the general election.

In the absence of a Presidential Threshold provision for political parties or coalitions of political parties to nominate candidates for President and Vice President, it will further increase competition between political parties, not as before which was only controlled by major political parties in the nomination of President and Vice President. This condition will also encourage the application of the principles of democratic elections.

\section{CONCLUSION}

Based on the discussion and analysis above, the authors can draw the following conclusions: the threshold provisions or Presidential Threshold for the election of President and Vice President in 2004 implemented a Presidential Threshold of 15\% of DPR votes or $20 \%$ of valid votes nationally obtained by political parties or coalitions of political parties in the DPR election. The Presidential and Vice-Presidential elections after 2004 to 2019 used the same Presidential Threshold, namely $20 \%$ of the DPR votes or $25 \%$ of nationally valid votes obtained by political parties or a combination of political parties in the DPR Election. Reconstruction of the regulation of the Presidential Threshold for the nomination of President and Vice President in Indonesia to be more appropriate if $0 \%$, this is an effort to present many qualified candidates for President and Vice President, so that people can see a more diverse pair. The $0 \%$ threshold becomes relevant to apply with a note that it is applied only to political parties that have passed the verification stage as participants in the general election. This condition will also encourage the application of the principles of democratic elections.

\section{REFERENCES}

1) A.Mukti, Fadjar, Tipe Negara Hukum (malang: bayumedia, 2004)

2) Al-Fatih, Sholahuddin, 'Akibat Hukum Regulasi Tentang Thersold Dalam Pemiliham Umum Legislatif Dan Pemilihan Presiden', Yudisial, 12 (2019)

3) Alok K. Bohara, Neil J. Mitchell, and Carl F. Mittendorff, 'Compound Democracy and the Control of Corruption: A Cross-Country Investigation', The Policy Studies Journal, 32.4 (2004), 481-99

4) Asshiddiqie, Jimly, Pokok-Pokok Hukum Tata Negara Indonesia Pasca Reformasi (Jakarta: Buana Ilmu Populer, 2007)

5) Dahl, Robert, Perihal Demokrasi, Menelajahi Teori Dan Praktik Demokrasi Secara Singkat (Jakarta: Penerbit yayasan Obor, 2011)

6) Ghoffar, Abdul, 'Problematika Presidential Theresold: Putusan Mahkamah Konstitusi Dan Pengalaman Di Negara Lain', Konstitusi, 15 (2018)

7) Huda, Ni'Matul, Dinamika Ketatanegaraan Indonesia Dalam Putusan Mahkamah Konstitusi (Yogyakarta: FH UII Press, 2011)

8) Indarti, Erlyn, 'Diskresi Dan Paradigma: Sebuah Telaah Filsafat Hukum', 2010

9) Jamaluddin Ghafur, Allan Fatchan Gani Wardhana, Presidential Threshold” Sejarah, Konsep Dan Ambang Batas Persyaratan Pencalonan Dalam Tata Hukum Di Indonesia (Malang: Setara Press, 2019)

10) Jamaludin, Tetep, 'Kesuksesan Dan Problematika Pemilihan Kepala Daerah Secara Langsung Di Indonesia', Jurnal Etika \& Pemilu, 4.1 (2018), 75-89

11) Jimly Asshiddiqie, 'Gagasan Negara Hukum Indonesia', Jurnal Pembinaan Hukum Nasional, 2.3 (2017), 1-17

12) MD, Moh Mahfud, Politik Hukum Di Indonesia, Cetakan ke (Jakarta: Pers, Rajawali, 2014)

13) Nasef, Imam, and Ni'Matul Huda, Penataan Demokrasi Dan Pemilu Di Indonesia Pasca Reformasi (Jakarta: Kencana, 2017)

14) Surbakti, Ramlan, Integritas Pemilu 2014: Kajian Pelanggaran, Kekerasan, Dan Penyalahgunaan Uang Pada Pemilu 2014 (Jakarta: Kemitraan Partnership, 2014)

15) Suteki, and Galang Taufani, Metodologi Penelitian Hukum (Filsafat, Teori Dan Praktik) (Depok: Rajagrafindo Persada, 2018)

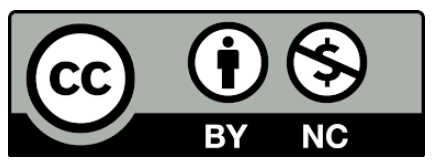

There is an Open Access article, distributed under the term of the Creative Commons Attribution - Non Commercial 4.0 International (CC BY-NC 4.0)

(https://creativecommons.org/licenses/by-nc/4.0/), which permits remixing, adapting and building upon the work for non-commercial use, provided the original work is properly cited. 